\title{
The effect of herbicides on winter false flax (Camelina sativa (L.) Crantz.)
}

\author{
Oksana Serdyuk $^{1 *}$, Victoria Trubina $^{1}$, and Lyudmila Gorlova ${ }^{1}$ \\ ${ }^{1}$ V.S. Pustovoit All-Russian Research Institute of Oil Crops, 17 Filatova street, Krasnodar, 350038, Russia
}

\begin{abstract}
The purpose of the research was to determine the effect of herbicides on winter false flax and to identify the preparation that does not effect negatively on crop plants. The research was carried out in 20182020 at V.S. Pustovoit All-Russian Research Institute of Oil Crops. The experiment scheme included herbicides with active ingredients (a.i.), which effectively decreased the number of weeds on the plots. The effectiveness of the preparations was more than $70 \%$ for different types of weeds. However, the variants with the application of preparations with a.i. clopyralid $300 \mathrm{~g} / \mathrm{l}$, S-Metolachlor $960 \mathrm{~g} / \mathrm{l}$, ethametsulfuronmethyl $750 \mathrm{~g} / \mathrm{kg}$ significantly decreased the plant density (by $18-32 \mathrm{pcs} / \mathrm{m}^{2}$ ) and seed yield (by $0.33-0.52$ $\mathrm{t} / \mathrm{ha}$ ) of false flax in comparison with the control. The oil content of seeds was significantly decreased in the variants with the herbicides with a.i. S-Metolachlor $960 \mathrm{~g} / \mathrm{l}$ with the application rate of $1.6 \mathrm{l} / \mathrm{ha}$ and ethametsulfuron-methyl $750 \mathrm{~g} / \mathrm{kg}$ (by 1.2-1.5\%). In other variants, the oil content of false flax seeds differed from the control insignificantly (by 0.3-0.4\%). It has been established that the preparation with a.i. quinmerac $83 \mathrm{~g} / \mathrm{l}+$ metazachlor $333 \mathrm{~g} / \mathrm{l}$ with the application rate of 2.0 or $2.5 \mathrm{l} / \mathrm{ha}$ should be applied to decrease the number of weeds in the sowings of winter false flax in the central zone of the Krasnodar region. This preparation, without having a toxic effect, increases the yield by $0.15-0.17 \mathrm{t} / \mathrm{ha}$ and does not decrease the plant density and oil content of false flax seeds.
\end{abstract}

\section{Introduction}

Currently, winter false flax (Camelina sativa (L.) Crantz.) is a promising oil crop of the Brassicaceae family due to its simple cultivation under various weather conditions in different soil and climatic conditions and early maturity [1]. Oil of false flax seeds is more oxystable and environmentally safe than other vegetable oils. It is used for food purposes, medicine manufacture, as well as biofuels, and high-value chemical raw materials with increasing frequency [2-5]. The cake remaining after pressing the oil from false flax seeds is a valuable feed with high content of protein (23.2-29.1\%), easily digestible for farm animals [6].

In false flax sowings in different regions of cultivation, there are weeds, which, competing with the crop, decrease the feeding area of false flax plants, leading to their decline [7]. During harvesting, weed seeds contaminate the seed material of false flax, and it is difficult to separate weed and crop seeds during the cleaning, which leads to their joint sowing the next year. It is possible to get a high yield of false flax seeds by using high-quality herbicides. However, most of the preparations currently applied on crops of the Brassicaceae family have a negative effect on the development of false flax plants, often leading to their death [8].
According to research by American scientists, false flax is tolerant to the action of only a few herbicides in the conditions of Montana: quinclorac, metolachlor [9]. Other scientists have developed mutant lines of false flax that are resistant to the action of imazethapyr and sulfosulfuron [10]. However, these preparations are not registered for crops of the Brassicaceae family in the Russian Federation. To this date, there are no herbicides in the list of preparations approved for use on false flax.

The purpose of the research was to determine the effect of herbicides on winter false flax and to identify the preparation that does not have a negative effect on crop plants.

\section{Materials and methods}

The research was carried out in 2018-2020 at the fields of V.S. Pustovoit All-Russian Research Institute of Oil Crops on winter false flax. The area of each plot was 12.0 $\mathrm{m}^{2}$; the number of replications was three.

The experimental scheme included herbicides approved in the Russian Federation for use on rapeseed with active ingredients (a.i.) belonging to different chemical classes (Table 1).

\footnotetext{
${ }^{*}$ Corresponding author: oserduk@mail.ru
} 
Table 1. Experiment scheme on the study of herbicides on winter false flax, 2018-2020

\begin{tabular}{|c|c|c|c|}
\hline $\begin{array}{l}\text { Variant (a.i. of } \\
\text { preparation) }\end{array}$ & $\begin{array}{c}\text { Applicati } \\
\text { on rate, } \\
1 / \mathrm{ha}, \\
\mathrm{kg} / \mathrm{ha}\end{array}$ & Chemical class & $\begin{array}{l}\text { Vegetative } \\
\text { stage of a } \\
\text { crop }\end{array}$ \\
\hline $\begin{array}{l}\text { Control (without } \\
\text { treatment) }\end{array}$ & . & - & - \\
\hline $\begin{array}{l}\text { Clopyralid } \\
300 \mathrm{~g} / 1\end{array}$ & 0.12 & Other substances & Rosette \\
\hline \multirow{2}{*}{$\begin{array}{l}\text { S-Metolachlor } \\
960 \mathrm{~g} / 1\end{array}$} & 1.4 & \multirow{2}{*}{$\begin{array}{l}\text { Chloroacetanilid } \\
\text { es (amides, } \\
\text { chloroacetamide } \\
\text { s) }\end{array}$} & \multirow[b]{2}{*}{$\begin{array}{c}\text { Pre- } \\
\text { emergence }\end{array}$} \\
\hline & 1.6 & & \\
\hline \multirow{2}{*}{$\begin{array}{l}\text { Quinmerac } \\
83 \mathrm{~g} / 1+ \\
\text { Metazachlor } \\
333 \mathrm{~g} / 1\end{array}$} & 2.0 & \multirow{2}{*}{$\begin{array}{c}\text { Other substances } \\
+ \\
\text { chloroacetanilide } \\
\text { s (amides, } \\
\text { chloroacetamide } \\
\text { s) }\end{array}$} & \multirow[b]{2}{*}{$\begin{array}{c}\text { Post- } \\
\text { emergence }\end{array}$} \\
\hline & 2.5 & & \\
\hline $\begin{array}{l}\text { Ethametsulfuron } \\
\text {-methyl } \\
750 \mathrm{~g} / \mathrm{kg}\end{array}$ & 0.02 & Sulfonylureas & $\begin{array}{c}\text { Post- } \\
\text { emergence }\end{array}$ \\
\hline
\end{tabular}

The treatment of plots with preparations was carried out at the development stage of false flax plants recommended for each preparation (similarly to the treatment of rapeseed sowings). The application rate of the working fluid was $300 \mathrm{l} / \mathrm{ha}$. The record of false flax plant density $\left(\mathrm{pcs} / \mathrm{m}^{2}\right)$ was carried out 3 weeks after treatment.

The oil content of winter false flax seeds after harvesting was determined on a Matrix-1 IR spectrometer.

The false flax plots were harvested with a Wintersteiger combine, the yield was corrected to $100 \%$ of purity and $8 \%$ of moisture content.

Statistical processing of the data of independent means for plant density, yield, and oil content was carried out using Student's $t$-test. The difference between the means exists when the actual values of the $t$-test exceed the theoretical values at the significance level of $0.05 ; 0.01$ or 0.001 .

\section{Research results}

The following weeds were identified in the sowings of winter false flax each year: common poppy (Papaver rhoeas L.), cleavers (Galium aparine L.), ivy-leaved speedwell (Veronica hederifolia L.), field bindweed (Convolvulus arvensis L.), green foxtail (Setaria viridis L.), etc. (Fig. 1).

The infestation level of false flax sowings with a complex of weed plants was high in all years of research - from 10 to $50 \mathrm{pcs} / \mathrm{m}^{2}$, which significantly decreased the feeding area of crop plants.

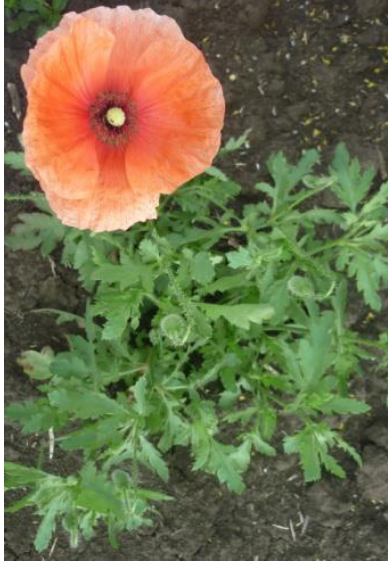

a

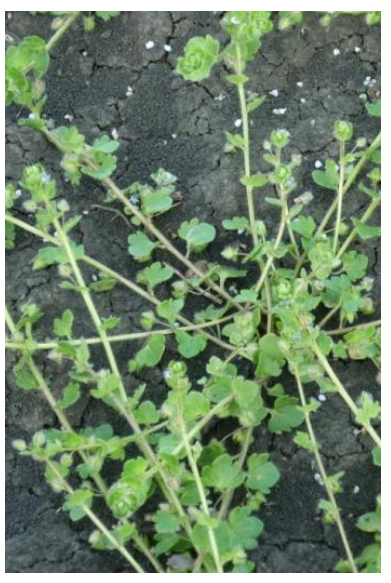

$\mathrm{c}$

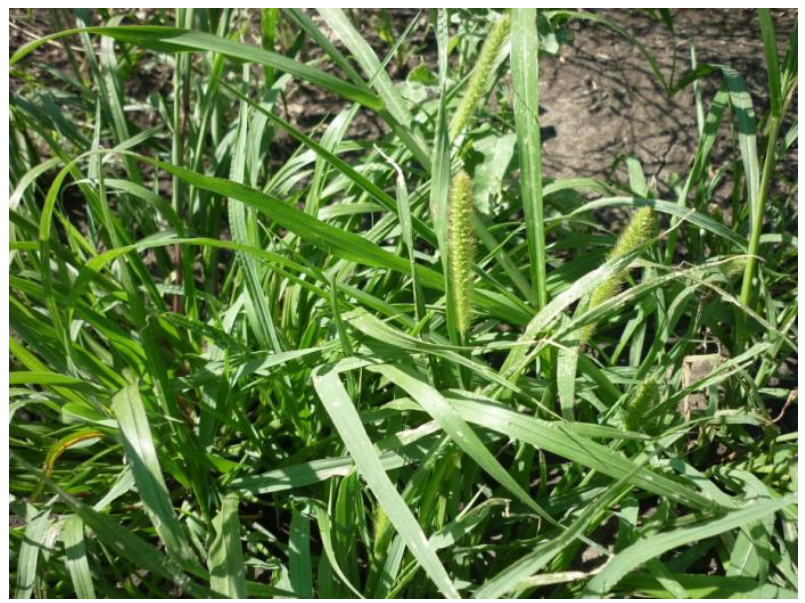

e

Fig. 1. Weed plants in winter false flax sowings:

a - common poppy (Papaver rhoeas L.);

$\mathrm{b}$ - cleavers (Galium aparine $\mathrm{L}$.);

c - ivy-leaved speedwell (Veronica hederifolia L.);

$\mathrm{d}$ - field bindweed (Convolvulus arvensis L.);

$\mathrm{e}$ - green foxtail (Setaria viridis L.).

The tested herbicides effectively decreased the number of weeds on the plots; the effectiveness of the preparations was more than $70 \%$ for different types of weeds. But at the same time, the a.i. of preparations negatively affected the growth and development of winter false flax to varying degrees, up to the complete death of plants (Table 2). 
Table 2. Plant density of winter false flax, 2018-2020

\begin{tabular}{|c|c|c|c|c|}
\hline $\begin{array}{l}\text { Variant } \\
\text { (a.i. of } \\
\text { preparation) }\end{array}$ & $\begin{array}{c}\text { Applicati } \\
\text { on rate, } \\
\text { 1/ha, } \\
\mathrm{kg} / \mathrm{ha}\end{array}$ & $\begin{array}{l}\text { Number } \\
\text { of } \\
\text { plants, } \\
\text { pcs } / \mathrm{m}^{2}\end{array}$ & $\begin{array}{l} \pm \text { to } \\
\text { the } \\
\text { contro } \\
1, \\
\mathrm{pcs} / \mathrm{m}^{2}\end{array}$ & $\begin{array}{l}\text { Actual } \\
t \text {-test }\end{array}$ \\
\hline $\begin{array}{l}\text { Control } \\
\text { (without } \\
\text { treatment) }\end{array}$ & - & 133 & - & - \\
\hline $\begin{array}{l}\text { Clopyralid } \\
300 \mathrm{~g} / 1\end{array}$ & 0.12 & 115 & -18 & $\begin{array}{c}3.30> \\
t_{\text {theor. }}\end{array}$ \\
\hline \multirow{2}{*}{$\begin{array}{l}\text { S-Metolachlor } \\
960 \mathrm{~g} / 1\end{array}$} & 1.4 & 111 & -22 & $\begin{array}{c}3.01> \\
t_{\text {theor. }}\end{array}$ \\
\hline & 1.6 & 106 & -27 & $\begin{array}{c}2.99> \\
t_{\text {theor. }}\end{array}$ \\
\hline \multirow{2}{*}{$\begin{array}{l}\text { Quinmerac } \\
83 \mathrm{~g} / 1+ \\
\text { Metazachlor } \\
333 \mathrm{~g} / 1\end{array}$} & 2.0 & 126 & -7 & $\begin{array}{c}1.87< \\
t_{\text {theor. }}\end{array}$ \\
\hline & 2.5 & 123 & -10 & $\begin{array}{c}2.03< \\
t_{\text {theor. }}\end{array}$ \\
\hline $\begin{array}{l}\text { Ethametsulfuro } \\
\text { n-methyl } \\
750 \mathrm{~g} / \mathrm{kg}\end{array}$ & 0.02 & 101 & -32 & $\begin{array}{c}5.21> \\
t_{\text {theor. }}\end{array}$ \\
\hline
\end{tabular}

${ }^{*}{ }_{\text {theor. }}=2.77$ at the significance level of 0.05

The plant density of false flax significantly decreased (by $18-32 \mathrm{pcs} / \mathrm{m}^{2}$ compared to the control) in the variants with preparations with the following a.i.: clopyralid 300 $\mathrm{g} / \mathrm{l}$, S-metolachlor $960 \mathrm{~g} / \mathrm{l}$ in both application rates, ethametsulfuron-methyl $750 \mathrm{~g} / \mathrm{kg}$. This is confirmed by the fact that the actual $t$-test $(2.99-5.21)$ in these variants significantly exceeds the theoretical values of the $t$-test (2.77). Decrease in the number of false flax plants per 1 $\mathrm{m}^{2}$ in variants with preparation containing a.i. quinmerac $83 \mathrm{~g} / \mathrm{l}+$ metazachlor $333 \mathrm{~g} / \mathrm{l}$ was insignificant (7-10 $\left.\mathrm{pcs} / \mathrm{m}^{2}\right)$.

The yield record of each variant carried out after harvesting of the plots showed treatment with preparations containing a.i. clopyralid $300 \mathrm{~g} / \mathrm{l}$, SMetolachlor $960 \mathrm{~g} / \mathrm{l}$ in both application rates, ethametsulfuron-methyl $750 \mathrm{~g} / \mathrm{kg}$ led to a significant decrease in the seed yield of winter false flax compared to the control (by $0.33-0.52 \mathrm{t} / \mathrm{ha}$ ), which is confirmed by the values of $t$-test (Table 3 ).

The preparation with a.i. quinmerac $83 \mathrm{~g} / \mathrm{l}+$ metazachlor $333 \mathrm{~g} / \mathrm{l}$ contributed to an increase in seed yield by $0.15-0.17 \mathrm{t} / \mathrm{ha}$ (depending on the application rate of the preparation) in comparison with the control.

Table 3. Seed yield of winter false flax, 2018-2020

\begin{tabular}{|l|c|c|c|c|}
\hline $\begin{array}{c}\text { Variant } \\
\text { (a.i. of } \\
\text { preparation) }\end{array}$ & $\begin{array}{c}\text { Applicatio } \\
\text { n rate, } \\
\text { 1/ha, kg/ha }\end{array}$ & Yield, t/ha & $\begin{array}{c} \pm \text { to } \\
\text { the } \\
\text { contro } \\
1, \mathrm{t} / \mathrm{ha}\end{array}$ & $\begin{array}{c}\text { Actual } \\
t \text {-test* }\end{array}$ \\
\hline $\begin{array}{l}\text { Control } \\
\text { (without } \\
\text { treatment) }\end{array}$ & - & 1.28 & - & - \\
\hline $\begin{array}{l}\text { Clopyralid } \\
300 \text { g/l }\end{array}$ & 0.12 & 0.95 & -0.33 & $\begin{array}{c}2.79> \\
\text { theor. }\end{array}$ \\
\hline $\begin{array}{l}\text { S- } \\
\text { Metolachlor } \\
960 \text { g/l }\end{array}$ & 1.4 & 0.93 & -0.35 & $\begin{array}{c}2.99> \\
t_{\text {theor. }}\end{array}$ \\
\cline { 2 - 5 } & 1.6 & 0.78 & -0.50 & $\begin{array}{c}3.02> \\
\text { theor. }\end{array}$ \\
\hline
\end{tabular}

\begin{tabular}{|l|c|c|c|c|}
\hline $\begin{array}{l}\text { Quinmerac } \\
83 \mathrm{~g} / \mathrm{l}+\end{array}$ & 2.0 & 1.45 & +0.17 & $\begin{array}{c}1.78< \\
\mathrm{t}_{\text {theor. }}\end{array}$ \\
\cline { 2 - 5 } $\begin{array}{l}\text { Metazachlor } \\
333 \mathrm{~g} / \mathrm{l}\end{array}$ & 2.5 & 1.43 & +0.15 & $\begin{array}{c}1.61< \\
\mathrm{t}_{\text {theor. }}\end{array}$ \\
\hline $\begin{array}{l}\text { Ethametsulf } \\
\text { uron-methyl } \\
750 \mathrm{~g} / \mathrm{kg}\end{array}$ & 0.02 & 0.76 & -0.52 & $\begin{array}{c}3.21> \\
\mathrm{t}_{\text {theor. }}\end{array}$ \\
\hline
\end{tabular}

${ }^{*} t_{\text {theor. }}=2.77$ at the significance level of 0.05

The biochemical analysis of seeds of winter false flax showed that on average over three years of research, the oil content significantly decreased (by $1.2-1.5 \%$ ) in the variants with preparations containing a.i. S-Metolachlor $960 \mathrm{~g} / \mathrm{l}$ with an application rate of $1.6 \mathrm{l} / \mathrm{ha}$ and ethametsulfuron-methyl $750 \mathrm{~g} / \mathrm{kg}$ (Table 4). In all other variants, the oil content of false flax seeds did not differ significantly from the control (by 0.3-0.4\%).

Table 4. Oil content of seeds of winter false flax, 2018-2020

\begin{tabular}{|l|c|c|c|c|}
\hline \multicolumn{1}{|c|}{$\begin{array}{c}\text { Variant } \\
\text { (a.i. of } \\
\text { preparation) }\end{array}$} & $\begin{array}{c}\text { Applicatio } \\
\text { n rate, } \\
1 / \mathrm{ha}, \mathrm{kg} / \mathrm{ha}\end{array}$ & $\begin{array}{c}\text { Oil } \\
\text { content, } \%\end{array}$ & $\begin{array}{c} \pm \text { to the } \\
\text { control, } \\
\%\end{array}$ & $\begin{array}{c}\text { Actual } \\
t \text {-test }\end{array}$ \\
\hline $\begin{array}{l}\text { Control } \\
\text { (without } \\
\text { treatment) }\end{array}$ & - & 40.8 & & - \\
\hline $\begin{array}{l}\text { Clopyralid } \\
300 \mathrm{~g} / \mathrm{l}\end{array}$ & 0.12 & 40.5 & -0.3 & $\begin{array}{c}1.37< \\
\text { theor. }\end{array}$ \\
\hline $\begin{array}{l}\text { S- } \\
\text { Metolachlor } \\
960 \mathrm{~g} / \mathrm{l}\end{array}$ & 1.4 & 40.4 & -0.4 & $\begin{array}{c}1.43< \\
\mathrm{t}_{\text {theor. }}\end{array}$ \\
\cline { 2 - 5 } & 1.6 & 39.6 & -1.2 & $\begin{array}{c}2.79> \\
\text { theor. }\end{array}$ \\
\hline $\begin{array}{l}\text { Quinmerac } \\
83 \mathrm{~g} / \mathrm{l}+\end{array}$ & 2.0 & 40.5 & -0.3 & $\begin{array}{c}1.41< \\
\mathrm{t}_{\text {theor. }}\end{array}$ \\
\cline { 2 - 5 } $\begin{array}{l}\text { Metazachlor } \\
333 \mathrm{~g} / \mathrm{l}\end{array}$ & 2.5 & 40.5 & -0.3 & $\begin{array}{c}1.39< \\
\mathrm{t}_{\text {theor. }}\end{array}$ \\
\hline $\begin{array}{l}\text { Ethametsulf } \\
\text { uron-methyl } \\
750 \mathrm{~g} / \mathrm{kg}\end{array}$ & 0.02 & 39.3 & -1.5 & $\begin{array}{c}2.99> \\
\mathrm{t}_{\text {theor. }}\end{array}$ \\
\hline
\end{tabular}

${ }^{*} t_{\text {theor. }}=2.77$ at the significance level of 0.05

Figure 2 shows the plots of winter false flax: the control variant and the variant with the herbicide containing a.i. quinmerac $83 \mathrm{~g} / 1+$ metazachlor $333 \mathrm{~g} / \mathrm{l}$ with application rate of $2.0 \mathrm{l} / \mathrm{ha}$. The difference in the number of weeds between the variants is clearly visible: there are significantly fewer weeds in the variant with the herbicide application. The preparation did not have a significant negative effect on the plant density of winter false flax. 


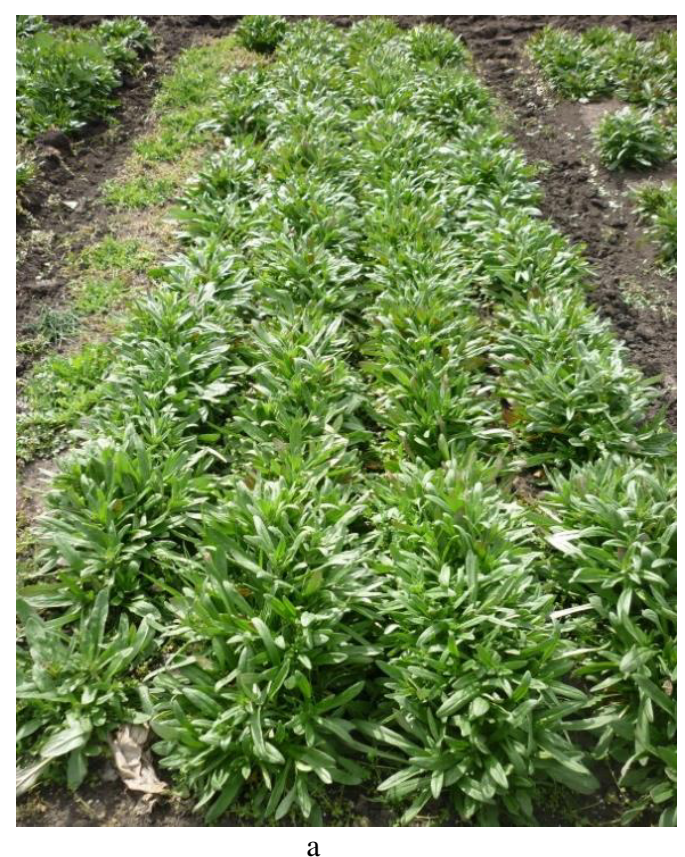

a

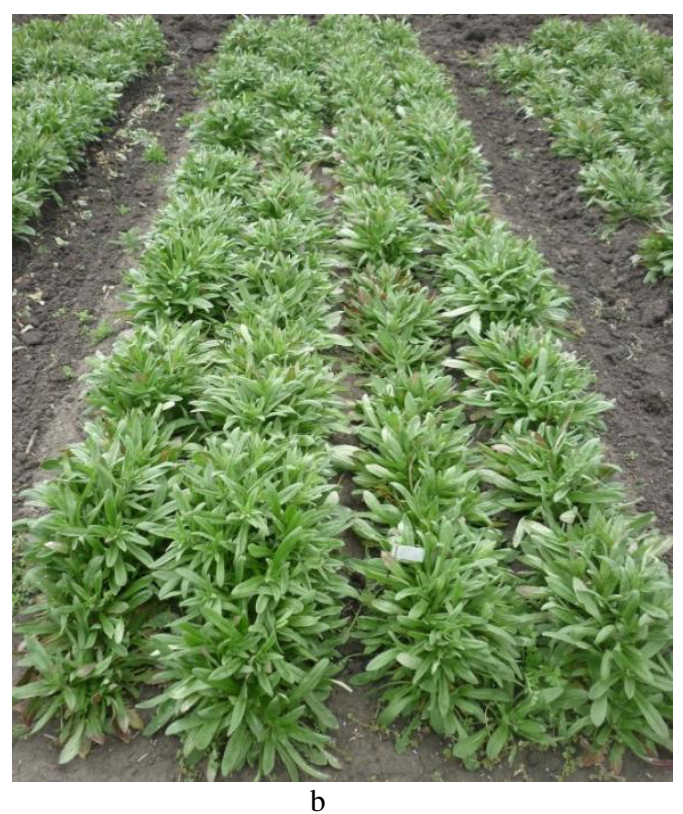

Fig. 2. A plot of winter false flax: a - control (without treatment),

6 - treated with the preparation containing a.i. quinmerac $83 \mathrm{~g} / \mathrm{l}$ + metazachlor $333 \mathrm{~g} / \mathrm{l}$ in the application rate of $2.0 \mathrm{l} / \mathrm{ha}$

\section{Conclusions}

The herbicide with a.i. quinmerac $83 \mathrm{~g} / \mathrm{l}+$ metazachlor $333 \mathrm{~g} / \mathrm{l}$ in the application rate of 2.0 or $2.5 \mathrm{l} / \mathrm{ha}$ should be applied to decrease the number of weeds in the sowings of winter false flax in the central zone of the Krasnodar region. This herbicide does not have a toxic effect on false flax plants, does not decrease the plant density and oil content of false flax seeds, increasing the yield by 0.15 $0.17 \mathrm{t} / \mathrm{ha}$.

\section{References}

1. M. K. Walia, F. Zanetti, R. W.Gesch, M. Krzyżaniak, C. Eynck, D. Puttick, E. Alexopoulou et al, Industrial Crops and Prod. 169, $113639 \quad$ (2021) https://doi.org/10.1016/j.indcrop.2021.113639

2. M. C. Campbell, A. F. Rossi and W. Erskine, Crop and Pasture Science 64(4), 388-398 (2013) https://doi.org/10.1071/CP13054

3. S. K. Gupta, Breeding Oilseed Crops for Sustainable Production. Opportunities and Constraints. Chapter 3 - Brassicas, 33-53 (2016) https://doi.org/10.1016/B978-0-12-801309-0.00003-3

4. S. Chaturvedi, A. Bhattacharya, S. K. Khare, G. Kaushik, Handbook of Environmental Materials Management. Camelina sativa: An Emerging Biofuel Crop, 1-38 (2017) https://link.springer.com/referenceworkentry/10.1007 \%2F978-3-319-58538-3 110-1

5. V. D. de Mello, I. Dahlman, M. Lankinen, S. Kurl, L. Pitkänen, D. E. Laaksonen, U. S. Schwab end A. T. Erkkilä, Nutrition \& Diabetes, 9, 1 (2019) https://doi.org/10.1038/s41387-018-0069-2

6. R. M. Harveson, D. K. Santra, M. L. Putnam, M. Curtis, and A. D. Pavlista, Plant Health Progress (2011) https://doi.org/10.1094/PHP-2011-1014-01$\underline{\mathrm{BR}}$

7. M. Leclère, M.-H. Jeuffroy, A. Butier, C. Chatain end C. Loyce, Industrial Crops and Prod. 140, 111605 (2019) https://doi.org/10.1016/j.indcrop.2019.111605

8. N. George, S. Watkins, B. Hanson, J. Hollingsworth and S. Kaffka, Division of Agricult. and Natur. Resources

(2014) https://ucanr.edu/repository/fileaccess.cfm?article $=15$ 8318\&p=DZSGWB

9. P. Jha and R. N. Stougaard, Weed Technol., 27 4, 712717 (2013) DOI:10.1614/WT-D-13-00061.1

10. D. T. Walsh, E. M. Babiker, I. C. Burke tnd S. H. Hulbert, Molec. Breed. 30 1053-1063 (2012) https://doi.org/10.1007/s11032-011-9689-0 